\title{
Infant mortality due to congenital malformations in the Autonomous City of Buenos Aires (1998-2015): Spatial, temporal analysis and relation to the socioeconomic status
}

\author{
Rubén A. Bronberg, M.D. ${ }^{a}$ and José E. Dipierri, M.D. ${ }^{b}$
}

a. Unit of Medical and Population Genetics, Division of Neonatology, Department of Mother, Child and Youth Health, Hospital General de Agudos “Dr. J. M. Ramos Mejía," Autonomous City of Buenos Aires.

b. High-Altitude Biology Institute, Universidad Nacional de Jujuy, San Salvador de Jujuy.

E-mail address:

Rubén A. Bronberg, M.D. rabronberg@intramed.net

Funding:

None.

Conflict of interest:

None.

Received: 7-22-2018

Accepted: 12-18-2018

\begin{abstract}
Introduction. In Argentina, congenital malformations $(\mathrm{CM})$ account for the second cause of death among infants younger than 1 year. Objective. To analyze spatial and temporal variation in infant mortality due to $\mathrm{CM}$ in the Autonomous City of Buenos Aires and its relation to a socioeconomic development indicator.

Materials and methods. Births and deaths among infants younger than 1 year were coded using the International Classification of Diseases (ICD-10); data were provided by the Ministry of Health. Geographical areas: northern, central and southern. Thenervous system, the cardiovascular system, chromosomal abnormalities, and 28 specific malformations were evaluated. Infant mortality rate due to $\mathrm{CM}$ (IMR-CM) and the percentage of deaths from CM (PD-CM) were estimated in 3 periods (1998-2003, 2004-2009, 2010-2015). Secular trend and risk of death were estimated using the Poisson regression model. A socioeconomic development indicator correlated to the IMR-CM and the PD-CM was obtained by means of a principal component analysis.

Results. The IMR-CM and the PD-CM had, respectively, a negative and positive secular trend with statistical significance, and exhibited a differentiation by areas. The IMR-CM values decreased for central nervous system and cardiovascular system malformations, and increased for chromosomal abnormalities $(p<0.05)$. The IMR-CM and the PD-CM were positively and negatively correlated, respectively, with the socioeconomic indicator $(p<0.05)$.

Conclusion. Infant mortality indicators due to $\mathrm{CM}$ in the Autonomous City of Buenos Aires are spatially and temporally heterogeneous, and are related to the socioeconomic characteristics of the areas.
\end{abstract}

Key words: infant mortality, congenital anomalies.

http: / / dx.doi.org/10.5546/aap.2019.eng.171

To cite: Bronberg RA. Dipierri JE. Infant mortality due to congenital malformations in the Autonomous City of Buenos Aires (1998-2015): Spatial, temporal analysis and relation to the socioeconomic status. Arch Argent Pediatr 2019;117(3):171-178.

\section{GLOSSARY}

CABA: Autonomous City of Buenos Aires.

CM: congenital malformations.

IM: infant mortality.

IMR-CM: infant mortality rate due to $\mathrm{CM}$.

PCA: principal component analysis. PD-CM: proportion of deaths from CM. ST: secular trend.

\section{INTRODUCTION}

In most Latin American countries, deaths from congenital malformations (CM) among infants younger than one year are ranked from second to fifth place and contribute between $2 \%$ and $27 \%$ of total infant mortality (IM) rates. ${ }^{1}$

Over the last decades, in countries with different levels of development, the following pattern has been observed: a reduction of total IM, the control of infectious diseases and nutritional deficiencies, a reduction of IM rate due to CM (IMR-CM) and an increase in the percentage of infant deaths due to CM (PD-CM). ${ }^{2-6}$

According to Rosano et al. $(2000),{ }^{2}$ the IMR-CM is higher in the poorest countries, and the PD-CM higher in the most developed ones. In Argentina, the less developed populations, with lower PD-CM and higher percentages of unmet basic needs, are in the north of the country. ${ }^{7}$

The Autonomous City of Buenos Aires (CABA) is located in the area with the highest human development index (HDI) (0.889) of Argentina and shows the lowest national percentages in terms of population with public coverage $(17.7 \%)$, unmet basic needs $(7.0 \%)$ and illiteracy $(0.5 \%){ }^{8}$ 
In large cities, current urban structures and dynamics lead to socioterritorial transformations evidenced by territorial inequalities and microdifferentiations, and spatial discontinuities. ${ }^{9}$ The Autonomous City of Buenos Aires is no exception to this phenomenon, where a marked socioterritorial, ${ }^{10}$ demographic, ${ }^{11}$ and demogenetic ${ }^{12}$ segregation, and a mixed metropolitan growth (dispersion/polycentrism) can be observed. ${ }^{13}$ This spatial differentiation is also reflected in health indicators. ${ }^{14,15}$

The objective of this study was to analyze the spatial and temporal variation of the IMR-CM and the $\mathrm{PD}-\mathrm{CM}$ in the $\mathrm{CABA}$, and its relation to a socioeconomic development indicator.

\section{MATERIALS AND METHODS}

Population-based study based on data on infant births and deaths that occurred between 1998 and 2015, which were collected by the Health Statistics and Information Department (Dirección de Estadística e Información de Salud, DEIS) of the Ministry of Health of Argentina. ${ }^{16}$

Non-linkable information was collected and analyzed from secondary sources of public information with the corresponding statistical confidentiality safeguard, thus consent was not required.

According to the place of residence of the mother, the following outcome measures were used: a) number of deaths in the first year of life; b) number of live births; c) cause of deaths from $\mathrm{CM}$, coded using the International Classification of Diseases, $10^{\text {th }}$ Revision (ICD-10) ${ }^{17}$ (codes Q00-Q99).

Regardless of sex, the IMR-CM (number of infant deaths from CM/1000 live births [LBs]) and the PD-CM (number of infant deaths from $\mathrm{CM} / 100$ deaths) were estimated for the entire CABA, 28 electoral districts and 15 municipalities distributed in 3 geographical areas (northern, central and southern) defined by the General Department of Statistics and Censuses (Dirección General de Estadistica y Censos) of the CABA.

Due to changes in the source of data used, death registration was carried out taking into account electoral districts and municipalities in different years. From 1998 to 2010, the geographical areas were defined based on the electoral districts: a) northern 16, 17, 18, 19; b) central 5, 6, 7, 8, 9, 10, 11, 12, 13, 14, 15, 20, 25, $26,27,28$; c) southern $1,2,3,4,22,23,21,24$. From 2011 to 2015 , they were defined based on the municipalities: a) northern 2, 13, 14; b) central 3,
5, 6, 7, 11, 12, 15; c) southern 4, 8, 9, 10.

IMR-CM and PD-CM confidence intervals were calculated as per Poisson distribution, which is adequate for low frequency events.

According to the applied mathematical model, the total period was divided into three subgroups: 1998-2003, 2004-2009, and 2010-2015. The secular trend (ST) throughout the entire period and the variation of risk of death for the 2010-2015 subperiod in relation to the baseline (1998-2003) were estimated using Poison regression models, using deaths from CM during the first year of life as a dependent outcome measure, the units of time as independent outcome measures, and total of deaths or live births as the reference population. To this end, the statistical software package used was Stata 12.1.

Temporal variation of IMR-CM and PD$\mathrm{CM}$ related to 28 specific malformations was estimated for the CABA and/or the geographical areas according to the following subgroups: a) central nervous system (CNS, Q00-Q079); b) cardiovascular system (CVS, Q200-Q289); c) chromosomal abnormalities (Q900-Q999).

To determine a single factor summarizing the effect of socioeconomic and demographic factors, the principal component analysis (PCA) was used with the percentage values of the following standardized outcome measures regarding the municipalities (2011-2015 data): a) population using only the public health care system; b) population using only the private health care system; c) population of students with academic failure; d) population with an income below the total market basket measure; e) population below the poverty line; f) population with unmet basic needs; g) substandard housing; h) unemployed individuals (General Department of Statistics and Censuses of the CABA) ${ }^{18}$ Pearson's test was used to correlate the first component of the PCA to the IMR-CM and the PD-CM.

\section{RESULTS}

The IMR-CM tended to diminish, whereas the opposite occurred with the PD-CM, showing a clear increase in the 3 geographical areas (Table 1, Figure 1).

The IMR-CM for the entire city, for the three subperiods, was $2.89,2.45$ and $2.55 \%$ with a significantly negative ST (-0.009) for the whole period. In the CABA, the IMR-CM decreased $0.9 \%$ per year. If the $2010-2015$ subperiod is compared to the 1998-2003 baseline subperiod, the risk of death from $\mathrm{CM}$ in the first year of 
life reduced significantly, by $12 \%$. Regarding the areas, the IMR-CM exhibited a negative ST that was not statistically significant. In the 3 periods, the highest IMR-CM was observed in the southern area, followed by the central and the northern areas (Table 1, Figures 1 and 2).

In the three subperiods, the PD-CM for the entire city was $27.6 \%, 29.6 \%$, and $32.0 \%$. The ST for the entire period (1998-2015) was significantly positive (0.014). For each year, the PD-CM increased by $1.4 \%$. If the $2010-2015$ subperiod is compared to the 1998-2003 baseline period, the relative weight of CM as an IM cause increased significantly, by $16 \%$. As regards geographical

FIGURE 1. Infant mortality rate due to congenital malformations and percentage of deaths from congenital malformations in the Autonomous City of Buenos Aires and geographical areas throughout the entire period

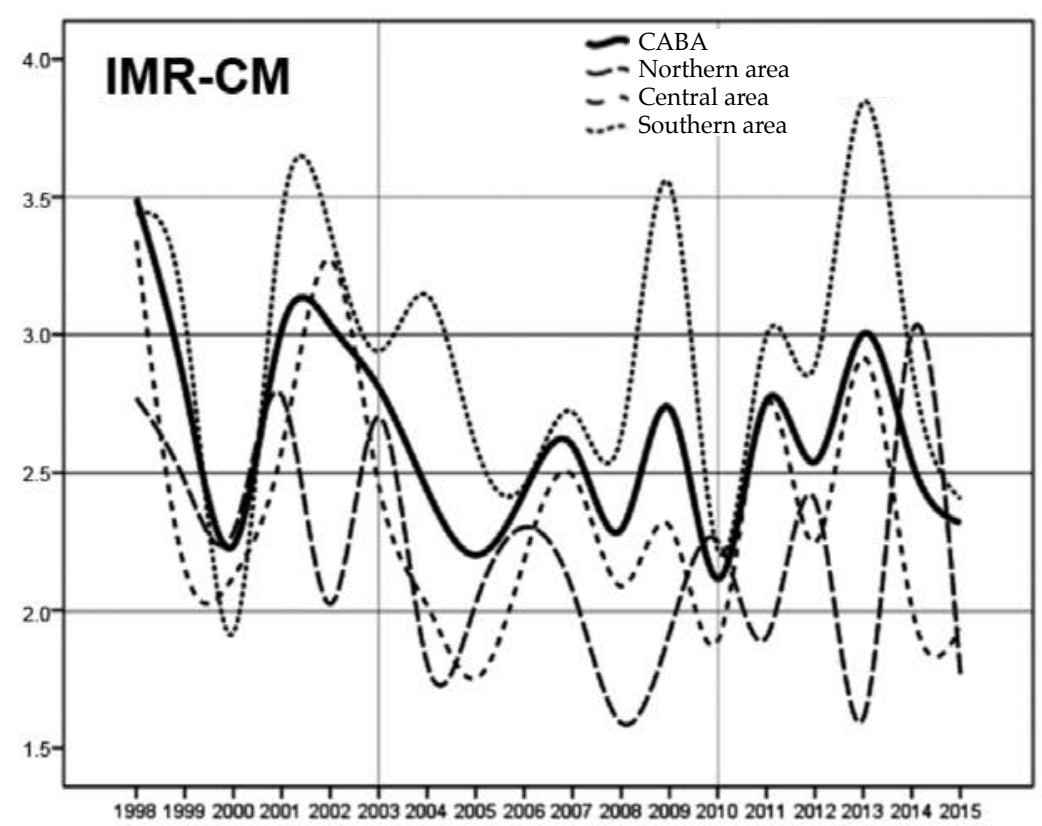

IMR-CM: infant mortality rate due to congenital malformations; CABA: Autonomous City of Buenos Aires.

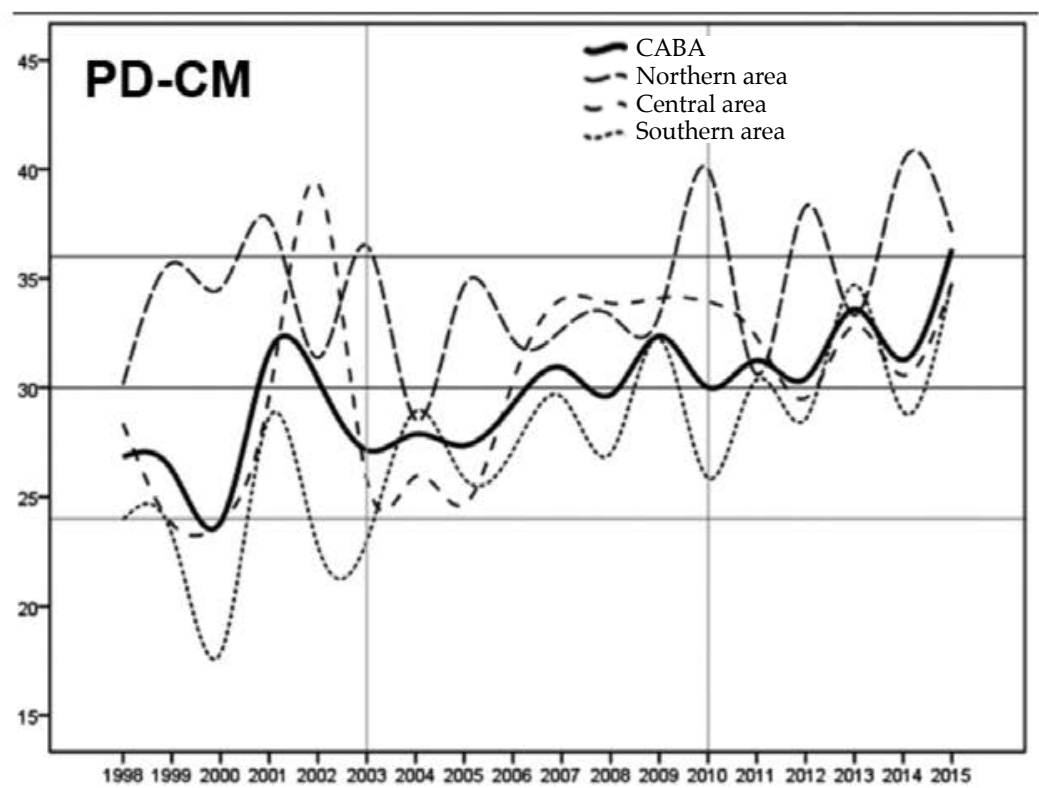

PD-CM: percentage of deaths from congenital malformations. 
areas, the PD-CM showed a positive ST, which was significant in the central and southern areas. In the 3 periods, the highest PD-CM was observed in the northern area, followed by the central and southern areas (Table 1, Figure 1).

For each year in the CABA, the specific IMR$\mathrm{CM}$ for CNS and CVS malformations reduced by $3.8 \%$ and $2.3 \%$, respectively, whereas the IMR-
CM for chromosomal abnormalities increased by $3.9 \%$ (Table 2). If the $2010-2015$ subperiod is compared to the 1998-2003 baseline subperiod, the risk of death in the first year of life due to CNS and CVS malformations reduced by $38 \%$ and $25 \%$, respectively, and increased by $49 \%$ for chromosomal abnormalities. The PD-CM by systems showed a behavior similar to the

TABLE 1. Infant mortality rate due to congenital malformations and proportion of deaths from congenital malformations, by subperiods, secular trend of the entire period and risk of the last period (2010-2015) in relation to the baseline (1998-2003) of the Autonomous City of Buenos Aires and geographical regions

\begin{tabular}{|c|c|c|c|c|c|}
\hline \multirow[t]{2}{*}{ CABA/Regions } & \multicolumn{3}{|c|}{$\begin{array}{l}\text { IMR-CM } \\
(95 \% \mathrm{CI}) \\
\end{array}$} & \multirow[t]{2}{*}{ ST } & \multirow[t]{2}{*}{ Risk } \\
\hline & 1998-2003 & 2004-2009 & 2010-2015 & & \\
\hline CABA & $2.89(2.57-3.21)$ & $2.45(2.16-2.74)$ & $2.55(2.25-2.84)$ & $-0.009^{*}$ & $0.88^{*}$ \\
\hline Northern & $2.51(1.83-3.18)$ & $1.95(1.35-2.55)$ & $2.16(1.51-2.81)$ & -0.012 & 0.86 \\
\hline Central & $2.64(2.18-3.11)$ & $2.13(1.73-2.54)$ & $2.30(1.90-2.71)$ & -0.010 & 0.87 \\
\hline \multirow[t]{2}{*}{ Southern } & $3.02(2.43-3.62)$ & $2.85(2.33-3.38)$ & $2.85(2.29-3.41)$ & -0.002 & 0.94 \\
\hline & & PD-CM & & & \\
\hline CABA & $27.6(24.5-30.7)$ & $29.6(26.1-33.1)$ & $32.0(28.3-35.7)$ & $0.014^{*}$ & $1.16^{*}$ \\
\hline Northern & $34.3(25.0-43.5)$ & $32.3(22.4-42.2)$ & $36.8(25.7-47.9)$ & 0.007 & 1.07 \\
\hline Central & $28.2(23.3-33.2)$ & $30.3(24.5-36.0)$ & $32.1(26.5-37.7)$ & $0.013^{*}$ & 1.14 \\
\hline Southern & $23.3(18.8-27.9)$ & $28.6(23.3-33.8)$ & $30.3(24.3-36.3)$ & $0.022^{*}$ & $1.30^{*}$ \\
\hline
\end{tabular}

* Significance level of $\mathrm{p}<0.05$; $95 \%$ CI: $95 \%$ confidence interval; IMR-CM: infant mortality rate due to congenital malformations; PD-CM: percentage of deaths from congenital malformations; ST: secular trend; CABA: Autonomous City of Buenos Aires.

FIGURE 2. Geographical areas (northern, central and southern), sub-divided into electoral districts colored by quartiles according to the infant mortality rate due to congenital malformations

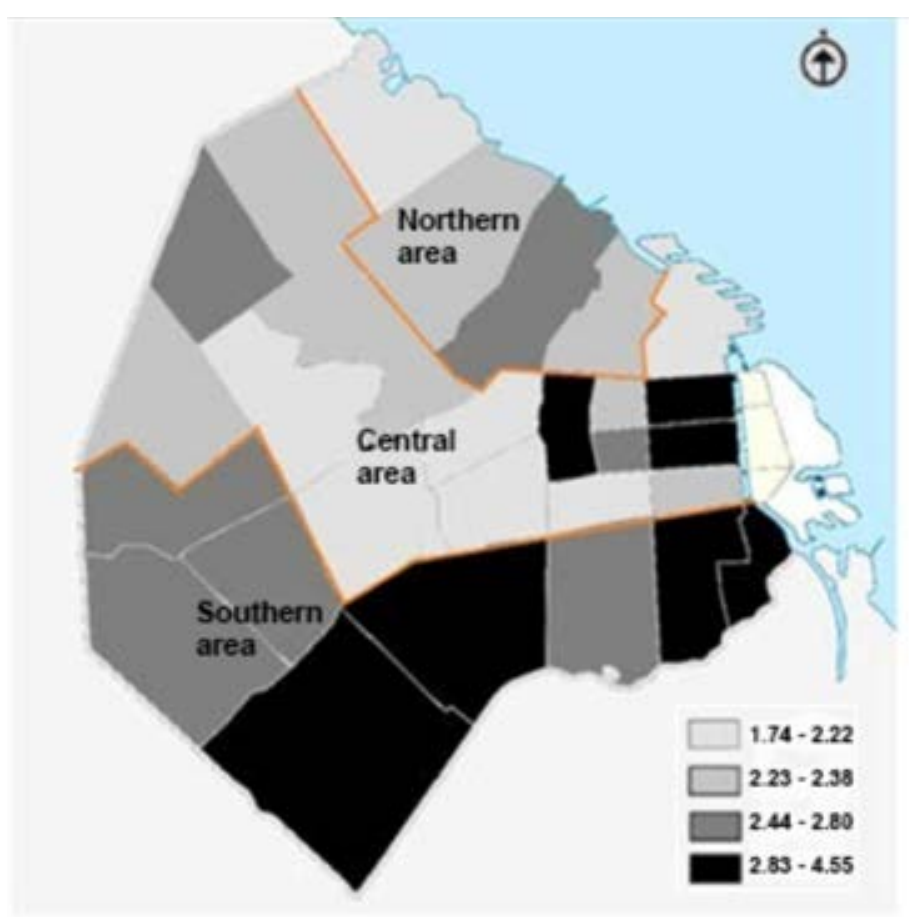


IMR-CM (Table 2). If the 2010-2015 subperiod is compared to the 1998-2003 baseline subperiod, the relative weight of $\mathrm{CM}$ as an IM cause due to CNS and CVS malformations reduced by $30 \%$ and $15 \%$, respectively, and increased by $70 \%$ for chromosomal abnormalities.

The specific IMR-CM for anencephaly and spina bifida showed a negative ST and a statistically significant risk reduction. However, patent ductus arteriosus, holoprosencephaly, and trisomy 18 showed a positive ST and a statistically significant higher risk (Table 3).

The first component of the PCA that accounts for the $72.8 \%$ of variance $-0.946 \times(\mathrm{a})-0.798 \times$ (b) $+0.735 \times(\mathrm{c})+0.933 \times(\mathrm{d})+0.960 \times(\mathrm{e})+0.910$ $\times(\mathrm{f})+0.653 \times(\mathrm{g})+0.839 \times(\mathrm{h})-$ indicates that the higher its value, the lower the level of socioeconomic development, and shows a marked differentiation by areas: being the highest value observed in the southern area (108) followed by the central (64.1) and northern areas (16.3). For the entire CABA, a positive and significant correlation $(\mathrm{r}=0.716 ; p<0.002)$ of the first PCA component with the IMR-CM was observed, and a significant, negative correlation with the PD$\mathrm{CM}(\mathrm{r}=-0.545 ; p<0.036)$ (Figure 3). Regarding the areas, correlations of the IMR-CM and the PD$\mathrm{CM}$ with the first component were of the same sign as the entire CABA, but were not statistically significant.

\section{DISCUSSION}

There is no data regarding the analysis of the epidemiology of infant mortality due to $\mathrm{CM}$ in large cities. In Argentina, during the 2002-2006 period, $22.7 \%$ of infant deaths were attributed to $\mathrm{CM}$; for the same period, this percentage was of $28.4 \%$ in the CABA. ${ }^{6}$

In brief, it can be observed that all parameters of infant deaths from CM analyzed are spatially

TABLE 2. Infant mortality rate due to congenital malformations and proportion of deaths from congenital malformations. by systems and subperiods, secular trend and risk of the last period (2010-2015) in relation to the baseline (1998-2003) of the Autonomous City of Buenos Aires and geographical areas

\begin{tabular}{|c|c|c|c|c|c|c|}
\hline \multirow[t]{2}{*}{ System } & \multirow[t]{2}{*}{$\begin{array}{l}\text { CABA } \\
\text { Areas }\end{array}$} & \multicolumn{4}{|c|}{$\begin{array}{c}\text { IMR-CM (10 }) \\
(95 \% \mathrm{CI})\end{array}$} & \multirow[b]{2}{*}{ Risk } \\
\hline & & 1998-2003 & 2004-2009 & $2010-2015$ & ST & \\
\hline \multirow{4}{*}{$\begin{array}{l}\text { CNS } \\
\text { (includes } \\
\text { neural tube } \\
\text { closure defects) }\end{array}$} & CABA & $4.42(3.16-5.68)$ & $2.86(1.88-3.85)$ & 2.73 (1.77-3.7) & $-0.038^{*}$ & $0.62^{*}$ \\
\hline & Northern & $2.85(0.57-5.14)$ & $2.44(0.33-4.55)$ & $1.75(0.00-3.60)$ & -0.034 & 0.61 \\
\hline & Central & $3.98(2.18-5.79)$ & $2.37(1.03-3.71)$ & $2.41(1.11-3.71)$ & -0.035 & $0.61^{*}$ \\
\hline & Southern & $4.78(2.42-7.14)$ & $2.99(1.30-4.69)$ & $3.18(1.31-5.05)$ & -0.041 & 0.67 \\
\hline \multirow[t]{4}{*}{ Cardiovascular } & CABA & 11.35 (9.34-13.37) & $8.66(6.95-10.37)$ & $8.53(6.83-10.24)$ & $-0.023^{*}$ & $0.75^{*}$ \\
\hline & Northern & 8.76 (4.75-12.77) & $6.50(3.05-9.95)$ & $7.42(3.60-11.24)$ & -0.020 & 0.85 \\
\hline & Central & $10.50(7.58-13.43)$ & 7.37 (5.00-9.74) & $8.80(6.31-11.28)$ & -0.020 & 0.84 \\
\hline & Southern & $12.40(8.60-16.20)$ & $10.58(7.39-13.77)$ & $9.17(5.99-12.34)$ & -0.016 & $0.74^{*}$ \\
\hline \multirow{5}{*}{$\begin{array}{l}\text { Chromosomal } \\
\text { abnormalities }\end{array}$} & CABA & $2.31(1.40-3.22)$ & $1.43(0.73-2.13)$ & $3.45(2.37-4.54)$ & $0.039^{*}$ & $1.49^{*}$ \\
\hline & Northern & $2.45(0.32-4.56)$ & $1.42(0.00-3.03)$ & $3.49(0.87-6.11)$ & 0.044 & 1.43 \\
\hline & Central & $2.26(0.91-3.62)$ & $1.52(0.45-2.60)$ & 3.35 (1.82-4.88) & 0.034 & 1.48 \\
\hline & Southern & $2.45(0.77-1.14)$ & $0.86(0.00-1.76)$ & $3.54(1.57-5.52)$ & 0.043 & 1.44 \\
\hline & \multicolumn{6}{|c|}{ PD-CM } \\
\hline \multirow{4}{*}{$\begin{array}{l}\text { CNS } \\
\text { (includes } \\
\text { neural tube } \\
\text { closure defects) }\end{array}$} & CABA & $15.3(10.9-19.6)$ & 11.7 (7.7-15.7) & $10.7(6.9-14.5)$ & $-0.028^{*}$ & $0.70^{*}$ \\
\hline & Northern & $11.4(2.3-20.5)$ & $12.5(1.7-23.3)$ & $8.1(0.0-16.7)$ & -0.020 & 0.71 \\
\hline & Central & $15.1(8.3-21.9)$ & $11.1(4.8-17.4)$ & $10.5(4.8-16.1)$ & -0.024 & 0.70 \\
\hline & Southern & $15.8(8.0-23.6)$ & $10.5(4.5-16.4)$ & $11.2(4.6-17.7)$ & -0.036 & 0.71 \\
\hline \multirow[t]{4}{*}{ Cardiovascular } & CABA & $39.3(32.3-46.2)$ & $35.4(28.4-42.4)$ & $33.5(26.8-40.2)$ & -0.013 & 0.85 \\
\hline & Northern & $35.0(19.0-50.9)$ & $33.3(15.7-51.0)$ & $34.3(16.7-52.0)$ & -0.006 & 0.98 \\
\hline & Central & 39.7 (28.7-50.8) & $34.5(23.4-45.6)$ & $38.2(27.4-48.9)$ & -0.010 & 0.96 \\
\hline & Southern & $41.0(28.5-53.6)$ & $37.1(25.9-48.3)$ & $32.2(21.0-43.3)$ & -0.013 & 0.79 \\
\hline \multirow{4}{*}{$\begin{array}{l}\text { Chromosomal } \\
\text { abnormalities }\end{array}$} & CABA & $8.0(4.8-11.1)$ & $5.8(3.0-8.7)$ & $13.6(9.3-17.8)$ & $0.047^{*}$ & $1.70^{*}$ \\
\hline & Northern & $9.8(1.3-18.2)$ & $7.3(0.0-15.6)$ & $16.2(4.0-28.3)$ & 0.054 & 1.66 \\
\hline & Central & $8.6(3.4-13.7)$ & $7.1(2.1-12.2)$ & $14.5(7.9-21.2)$ & $0.042^{*}$ & $1.70^{*}$ \\
\hline & Southern & $8.1(2.5-13.7)$ & $3.0(0.0-6.2)$ & $12.4(5.5-19.4)$ & 0.045 & 1.53 \\
\hline
\end{tabular}

* Significance level of $\mathrm{p}<0.05 ; 95 \%$ CI: $95 \%$ confidence interval; IMR-CM: infant mortality rate due to congenital malformations; PD-CM: percentage of deaths from congenital malformations; ST: secular trend; CABA: Autonomous City of Buenos Aires. 
heterogeneous and exhibit a differential zonal performance over time.
In Argentina, as well as in developed countries $^{2}$ and some Latin American countries, ${ }^{5}$

TABLE 3. Infant mortality rate due to specific congenital malformations, by malformations, secular trend and risk in the last period (2010-2015) in relation to the baseline period (1998-2003), by subperiods

\begin{tabular}{|c|c|c|c|c|c|c|}
\hline \multirow[t]{2}{*}{ Malformation } & \multirow[t]{2}{*}{$\begin{array}{l}\text { Code } \\
I C D\end{array}$} & \multicolumn{3}{|c|}{$\begin{array}{l}\text { IMR-CM (10 }) \\
(95 \% \mathrm{CI})\end{array}$} & \multirow[t]{2}{*}{ ST } & \multirow[t]{2}{*}{ Risk } \\
\hline & & 1998-2003 & 2004-2009 & 2010-2015 & & \\
\hline Anencephaly & Q000 & $24.7(15.3-34.1)$ & $12.8(6.21-19.4)$ & $8.72(3.27-14.2)$ & $-0.085^{*}$ & $0.35^{*}$ \\
\hline Encephalocele & Q010-9 & $2.39(0.00-5.32)$ & $1.88(0.00-4.41)$ & $1.90(0.00-4.44)$ & -0.001 & 0.79 \\
\hline Microcephalus & Q020 & $1.20(0.00-3.26)$ & $1.13(0.00-3.09)$ & $0.00(0.00-0.00)$ & -0.124 & - \\
\hline Hydrocephalus & Q039 & $6.37(1.59-11.2)$ & $3.76(0.19-7.34)$ & $3.79(0.19-7.39)$ & -0.041 & 0.60 \\
\hline Holoprosen cephaly & Q042 & $0.80(0.00-2.49)$ & $2.26(0.00-5.03)$ & $4.17(0.40-7.95)$ & $0.133^{*}$ & $5.23^{*}$ \\
\hline Brain hypoplasia & Q043 & $0.80(0.00-2.49)$ & $1.88(0.00-4.41)$ & $1.90(0.00-4.44)$ & 0.061 & 2.38 \\
\hline Spina bifida & Q050-9 & $2.39(0.00-5.32)$ & $0.75(0.00-2.35)$ & $0.76(0.00-2.37)$ & $-0.145^{*}$ & 0.38 \\
\hline $\begin{array}{l}\text { Discordant ventriculo } \\
\text { arterial connection }\end{array}$ & Q203 & $1.99(0.00-4.66)$ & $2.64(0.00-5.62)$ & $1.14(0.00-3.11)$ & -0.041 & 0.57 \\
\hline Double inlet ventricle & Q204 & $0.40(0.00-1.59)$ & $2.26(0.00-5.03)$ & $1.14(0.00-3.11)$ & 0.062 & 2.86 \\
\hline Ventricular septal defect & Q210-12 & $0.80(0.00-2.49)$ & $0.38(0.00-1.51)$ & $0.76(0.00-2.37)$ & 0.000 & 0.95 \\
\hline Tetralogy of Fallot & Q213 & $1.99(0.00-4.66)$ & $0.75(0.00-2.35)$ & $1.14(0.00-3.11)$ & -0.061 & 0.57 \\
\hline Hypoplastic left heart syndrome & Q234 & $3.98(0.20-7.76)$ & $3.76(0.19-7.34)$ & $4.93(0.83-9.03)$ & 0.007 & 1.24 \\
\hline Patent ductus arteriosus & Q250 & $0.80(0.00-2.49)$ & $3.01(0.00-6.21)$ & $7.97(2.75-13.2)$ & $0.174^{*}$ & $9.99^{*}$ \\
\hline Coarctation of aorta & Q251 & $0.80(0.00-2.49)$ & $1.13(0.00-3.09)$ & $0.38(0.00-1.52)$ & -0.010 & 0.48 \\
\hline Hypoplasia of lung & Q336 & $13.9(6.87-21.0)$ & $16.19(8.78-23.6)$ & $7.97(2.75-13.2)$ & -0.030 & $0.57^{*}$ \\
\hline Renal agenesis & Q601-2 & $1.20(0.00-3.26)$ & $2.26(0.00-5.03)$ & $2.66(0.00-5.67)$ & 0.064 & 2.22 \\
\hline Potter syndrome & Q606 & $1.20(0.00-3.26)$ & $1.51(0.00-3.76)$ & $1.14(0.00-3.11)$ & -0.007 & 0.95 \\
\hline Polycystic kidney & Q611-3 & $0.80(0.00-2.49)$ & $2.64(0.00-5.62)$ & $2.28(0.00-5.06)$ & 0.073 & 2.86 \\
\hline Thanatophoric short stature & Q771 & $0.00(0.00-0.00)$ & $0.38(0.00-1.51)$ & $1.14(0.00-3.11)$ & 0.307 & - \\
\hline Diaphragmatic hernia & Q790 & $13.9(6.87-21.0)$ & $12.1(5.66-18.4)$ & $12.1(5.70-18.6)$ & -0.003 & 0.87 \\
\hline Omphalocele & Q792 & $1.59(0.00-3.98)$ & $1.13(0.00-3.09)$ & $1.52(0.00-3.79)$ & 0.005 & 0.95 \\
\hline Gastroschisis & Q793 & $2.39(0.00-5.32)$ & $3.39(0.00-6.78)$ & $4.93(0.83-9.03)$ & 0.064 & 2.06 \\
\hline Down syndrome & Q900-9 & $8.76(3.16-14.4)$ & $2.64(0.00-5.62)$ & $9.10(3.53-14.7)$ & 0.010 & 1.04 \\
\hline Edwards syndrome & Q911-3 & $9.56(3.71-15.4)$ & $7.53(2.48-12.6)$ & $16.3(8.85-23.8)$ & $0.048^{*}$ & $1.71^{*}$ \\
\hline Patau syndrome & Q914-7 & $3.19(0.00-6.57)$ & $4.14(0.40-7.89)$ & $6.45(1.76-11.1)$ & 0.042 & 2.02 \\
\hline
\end{tabular}

* Significance level of $\mathrm{p}<0.05$; $95 \%$ CI: $95 \%$ confidence interval; IMR-CM: infant mortality rate due to congenital malformations; ST: secular trend.

FIGURE 3. Scatter plot of the infant mortality rate due to congenital malformations, the percentage of deaths from congenital malformations and the first principal component of socioeconomic outcome measures by municipalities
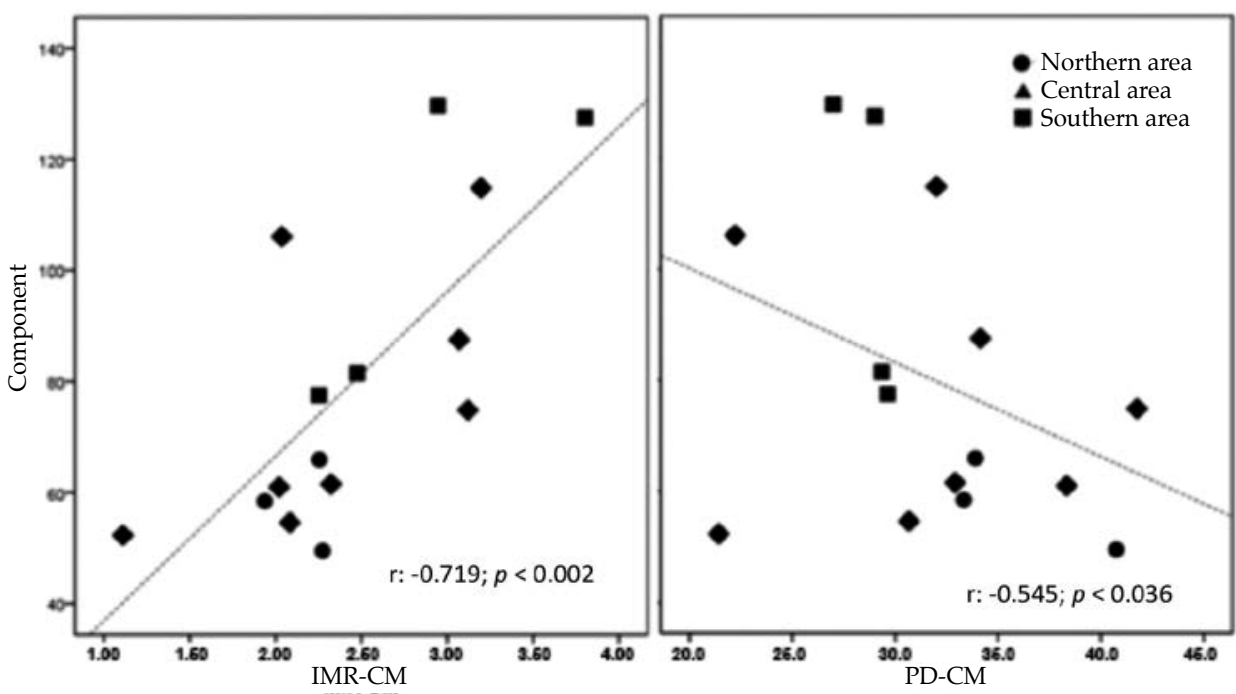

IMR-CM: infant mortality rate due to congenital malformations; PD-CM: percentage of deaths from congenital malformations. 
infant deaths from CM show a pattern in which a negative ST of IMR-CM and a positive ST of PD$\mathrm{CM}$ can be observed. In this regard, it can also be observed that, between 1998 and 2015, in the CABA -in spite of more favorable socioeconomic conditions when compared to the rest of the country- the IMR-CM decreased moderately (0.9\%/year), whereas the PD-CM increased (1.4\%/year). Even though the geographical areas of the CABA also show a negative -but not statistically significant-ST of the IMR$\mathrm{CM}$, the smallest decrease of this indicator was observed in the southern area. The PD-CM by areas, as expected according to the pattern (IMR$\mathrm{CM}$ with negative ST, PD-CM with positive ST), shows a positive $\mathrm{ST}$ in all the areas but increases significantly more in the southern area exhibiting the highest statistically significant zonal risk. Nevertheless, from a historical perspective, throughout all the periods, the northern area exhibits the lowest IMR-CM and the highest PD$\mathrm{CM}$, whereas the opposite occurs in the southern area. The same occurs when IM indicators are analyzed by years: the highest PD-CM can be observed in the northern area, and the highest IMR-CM in the southern area.

Since most deaths from $\mathrm{CM}$ are due to major structural malformations, specifically neural tube closure defects and heart malformations, the negative ST both for the IMR-CM and the specific PD-CM for these malformations can indirectly reflect efforts made at a national and local level to reduce its prevalence and treat these congenital anomalies at an early stage. ${ }^{6}$ To improve prenatal diagnosis and early neonatal surgery of congenital heart diseases, an integrated network of referral and timely treatment has been established through the National Congenital Heart Disease Program (Programa Nacional de CardiopatíasCongénitas). ${ }^{19}$ In addition, in Argentina, the enrichment of wheat flour with folic acid is mandatory since $2003 .{ }^{20}$ When analyzing the systems, a statistically significant negative ST can be observed for CNS and CVS malformations, and for specific CNS malformations; historically, the highest IMR$\mathrm{CM}$ and PD-CM can be generally observed in the southern area. Bronberg et al. (2011) estimated a reduction of $53 \%$ in the risk of mortality from anencephaly in Argentina, in the 1998-2007 period. ${ }^{21}$ In this study, at a national level, the specific mortality rate from anencephaly in the pre-fortification period was 3.10 (1998-2002), and $1.46(2005-2007)$ in the post-fortification period. In the $\mathrm{CABA}$, rates in the pre- and post-fortification periods were lower, 2.65 and 1.30, respectively. According to this study, in which the analysis period is extended (1998-2015) with data collected from the same source, the specific mortality rate from anencephaly continues decreasing, with a significant reduction in infant deaths from this cause by $65 \%$.

Even though, generally speaking, a reduction in the ST and a $25 \%$ reduction in the significant risk for mortality from CVS defects can be observed in this study, the ST of specific infant deaths from patent ductus arteriosus (PDA) and its risk are significantly positive, which could be attributed to limited access to treatment, prematurity complications associated with this condition and late diagnosis. ${ }^{22}$

Factors leading to a significant increase of the IMR-CM and PD-CM due to chromosome abnormalities are multiple, interact with one another and show a clear social differentiation: access to prenatal diagnosis, advanced maternal age, quality of prenatal diagnosis of chromosome abnormalities, access to elective abortion and reproductive characteristics as per place of residence. All these factors, in addition to the differential lethality of trisomies, might account for the increase in infant deaths related to chromosome abnormalities. Although, in all the geographical areas, the ST for the IMR-CM and PD-CM due to chromosome abnormalities is positive and not statistically significant, except for the PD-CM in the central area; in the 20102015 period, the highest values of IMR-CM and PD-CM from chromosomal abnormalities were observed in the southern and northern areas, respectively.

According to the PCA, the CABA shows heterogeneity of socioeconomic development by geographical areas, which is also confirmed by other observations. ${ }^{9-15}$ The least developed geographical region in the CABA would be the southern area, where, concomitantly, the highest and lowest values of IMR-CM and PD$\mathrm{CM}$, respectively, were observed. This would explain the positive correlation of the IMR-CM and the negative correlation of the PD-CM with the socioeconomic indicator, which shows a distinctive pattern characterized by an increased IMR-CM with a decline in development and the opposite with the PD-CM. This pattern has resulted in the use of the PD-CM as a socioeconomic proxy, which has already been verified in Chile, ${ }^{5}$ Argentina, ${ }^{7}$ and 36 countries 
from Europe, the Middle East, America, Asia and the Pacific. $^{2}$

The socio-spatial and socio-habitational structure of the CABA is the result of a long historical development, in which different socioeconomic, political and territorial factors, both at a metropolitan and national level, have been changing the conditions of access to land and housing in this area. Metropolitan differences and inequalities, due to the spatial dimension of socio-urban processes, constitute a complex subject matter, which is permeated by deep conceptual and methodological discussions. ${ }^{11}$ Socioeconomic spatial heterogeneities in the CABA would result in spatial differences in terms of health, as indicated by the epidemiology of IM due to $\mathrm{CM}$ analyzed in this study.

\section{CONCLUSION}

In spite of exhibiting an advanced stage of epidemiological transition of IM causes between 1998 and 2015, the CABA, concomitantly, shows a great heterogeneity of IM indicators due to $\mathrm{CM}$, which is consistent with the socioeconomic diversity of the geographical areas.

\section{REFERENCES}

1. WHO. Special Topic: The ten leading causes of death in countries of the Americas. In: Health Stastitics from the Americas. 2006. [Accessed on: July 10 ${ }^{\text {th }}$, 2018]. Available at: http:/ / www.paho.org/English/DD/AIS/HSA2006_ ST.pdf.

2. Rosano A, Botto LD, Botting B, Mastroiacovo P. Infant mortality and congenital anomalies from 1950 to 1994: an international perspective. J Epidemiol Community Health. 2000; 54(9):660-6.

3. Copeland G, Kirby RS. Using birth defects registry data to evaluate infant and childhood mortality associated with birth defects: an alternative to traditional mortality assessment using underlying cause of death statistics. Birth Defects Res A Clin Mol Teratol. 2007; 79(11):792-7.

4. Szot J. Mortalidad infantil por malformaciones congénitas: Chile, 1985-2001. Rev Chil Pediatr. 2004; 75(4):347-54.

5. Dipierri JE, Acevedo NE, Bronberg RA. Mortalidad infantil por malformaciones congénitas en Chile: análisis temporal y espacial, 1997-2011. Rev Panam Salud Pública. 2015; 38(5):380-7.

6. Bronberg R, Alfaro E, Chaves E, Dipierri J. Mortalidad infantil por malformaciones congénitas en Argentina: análisis del quinquenio 2002-2006. Arch Argent Pediatr. 2009; 7(3):203-11.
7. Bronberg R, Gutiérrez Redomero E, Alonso M, Dipierri J. Mortalidad infantil por malformaciones congénitas y condición socioeconómica: el caso de la Argentina. Rev Panam Salud Pública. 2012; 31(6):469-75.

8. Dirección General de Estadística y Censos (Ministerio de Hacienda GCBA). Anuario Estadístico 2015 Ciudad de Buenos Aires. [Accessedon: July $10^{\text {th }}, 2018$ ]. Available at: http: / / www.estadisticaciudad.gob.ar/eyc/ ?p=61948.

9. Marcos M, Mera G. La dimensión espacial de las diferencias sociales: Alcances y limitaciones metodológicoconceptuales de las herramientas estadísticas para abordar la distribución espacial intraurbana. Rev Univ Geogr. 2011;20(1):41-65.

10. ManzanoFA, VelázquezGA.Calidad de viday desigualdad en el área metropolitana de Buenos Aires. Análisis a nivel de fracción censal (2010). Cardinalis (Córdoba En línea). 2016; 4(6):19-44.

11. Di Virgilio MM, Marcos M, Mera G. Las ciudades dentro de la ciudad: características sociodemográficas y habitacionales de la Ciudad de Buenos Aires según sus tipos de hábitat. Poblac B Aires. 2015; 12(22):33-57.

12. Bronberg RA, Dipierri JE, Alfaro EL, Barrai I, et al. Isonymy structure of Buenos Aires city. Hum Biol. 2009; 81(4):447-61.

13. Usach N, Garrido-YserteR, Gallo-Rivera MT. Organización territorial y funcional de la metrópoli de Buenos Aires. EURE (Santiago). 2017; 43(128):55-80.

14. Grushka C, Baum D, Sanni L. Vivir y morir en las comunas de la Ciudad de Buenos Aires: un estudio de diferenciales. Poblac B Aires. 2013; 10(18):33-44.

15. Mazzeo V.La mortalidad dela primera infancia en la Ciudad de Buenos Aires en el período 1860-2002. Pap Poblac. 2007; 13(53):241-72.

16. Dirección de Estadística e Información deSalud. Ministerio deSalud y DesarrolloSocial. Indicadores Básicos. [Accessed on: July $10^{\text {th }}, 2018$ ]. Available at: http:/ / www.deis.msal. gov.ar/index.php/indicadores-basicos/.

17. Organización Panamericana de la Salud. Clasificación Internacional de Enfermedades y problemas relacionados con la salud. 10.a rev.; vol. 2. Washington, DC: OPS; 1995. [Accessed on: July $10^{\text {th }}, 2018$ ]. Available at: ais.paho.org/ classifications / Chapters/pdf/Volume2.pdf.

18. Dirección Genera de Estadística y Censos de la CABA. Anuario estadístico 2016. [Accessed on: July 10 $0^{\text {th }}, 2018$ ]. Available at: http:/ / www.estadisticaciudad.gob.ar/eyc/ wp-content/uploads/2017/10/anuario_estadistico_2016. pdf.

19. Chernovesky G. Programa nacional de cardiopatías congénitas. Rev Hosp Mat Inf Ramón Sardá. 2011; 30(1):38-41.

20. Calvo E. Fortificación con ácido fólico y defectos del tubo neural. Arch Argent Pediatr. 2008; 106(4):291-2.

21. Bronberg R, Alfaro E, Chaves E, Andrade A, et al. Mortalidadinfantilporanencefalia enla Argentina. Análisis espacial y temporal (1998-2007). Arch Argent Pediatr. 2011; 109(2):117-23.

22. Golombek SG, Sola A, Baquero H, Borbonet D, et al. Primer consenso clínico de SIBEN: enfoque diagnóstico y terapéutico del ductus arterioso permeable en recién nacidos pretérmino. An Pediatr (Barc). 2008; 69(5):454-81. 